Thiswould enablecountries of origin either to prevent such patent applications, or to require benefit-sharing arrangements with theapplicants. Developed countriesshould support - not block - this proposal.

As part of the implementation of the Convention on Biological Diversity, developing countries should also establish national arrangements for collecting and using biological resources and the knowledge associated with them, as well as for sharing the benefits from any commercial transactions with those communities which have developed thisknowledge.

Unfortunately current efforts by individual countries to review their national laws on intellectual property, in order to bringthem in line with their obligationsunder the TRIPS agreement, is likely to accelerate the biopiracy phenomenon. For this process now requires countries that previously forbade the patenting of life to allow patents on certain types of organisms and living processes.

With careful and intelligent legal and policy choices, developing countries can avoid some of the worst dangers that can arise from the implementation of their obligationsunder TRIPS. In thelongrun, however, a fundamental revision of multilateral trade rules is essential if the injustice inflicted by biopiracyon local communities and their indigenous knowledge is to be corrected.

Reprinted with permission from SciDev.Net, 23 August 2002. Copyright (c) 2002 by The Science and Development Network. All rights reserved.

* Sub-title and summary not from SciDev.Net; added with the permission by Himalayan Journal of Sciences

Martin Khor is director of the Third World Network - a non-profit international network that researches, publishes on, and organises events about issues relating to de velopment - which is based in Malaysia.

\section{This article is available online at}

http:// www.scidev.net/Opinions/index.cfm ?fuseaction=readopinions\&itemid $=128 \&$ language $=1$.

The Science and Development Network (SciDev.Net) aims to enhance the provision of reliableand authoritativeinformation on science and technology-related issues that impact on the economic and social development of developing countries. It is supported bythescientific journals Natureand Science, both of which have agreed to provide free access to a selected articles every week.

\title{
Menacing food commodities
}

\author{
Escalating trends of fraudulent practice in food \\ business has penetrated the 'whole food chain'
}

\section{Rajendra Uprety}

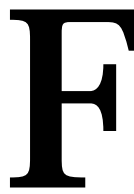
raudulent practices by our food industryareundermining public health in Nepal. Although news papers and media frequently cover them, fraudulent practices in the food business are becoming more rampant. Itishightimethat consumers, who spend a sizableproportion of their earnings on food, learn thebitter truth about theadulteration that has become "food business as usual."

Tests reported in the annual bulletin of the Department of Food Technology and Quality Control (DFTQC, HMG Nepal) reveal that food producers and distributors have been playing their dirty games for at least 20 years. A large number of marketed food items have been adulterated or contaminated (see Figure 1a); we will be discussing only a few of the more egregious cases.

According to a report in the DFTQC bulletin for 1998/99, over 90 percent of milk and milkproducts (asmentioned in thetext) were substandard due to the presence of mesophiliccontaminants (yeast, mould, coliform, Salmone la species and other few microorganisms) which resulted from adulteration of milk with unsafe water. The2000/ 2001 bulletin states that 14dairies havebeen producing dairy productsin Nepal, and that, for the most part, the quality of their productshas been deteriorating (seeFigure 1b). Theculprits includeAdhunic Dairy, Pushpa Dairy, Sainju Dairy and Kharipati Dairy, out of which the products of Pushpa Dairy and Adhunic Dairy were completely substandard during 1999-2001. In addition, 60 to $80 \%$ of the marketed products of Integrated Dairy, Silwal Dairy and Nepal Dairy were adulterated. FIGURE $\mathbf{l b}$ gives more details on the quality of dairy products consumed in past seven years.

There was a significant and almost continuous risein oil adulteration from 1995 to 2001 (see Figure 1c). Most mustard and rapeseed oil was found to be adulterated with thetoxic Argemoneand other cheaper oils. There isno reason to suspect that these oils are any safer today.

Noodles, though comparatively expensive, are widely consumed snacks, especially popular amongschool children. 48 percent of snack noodles and 42 percent of

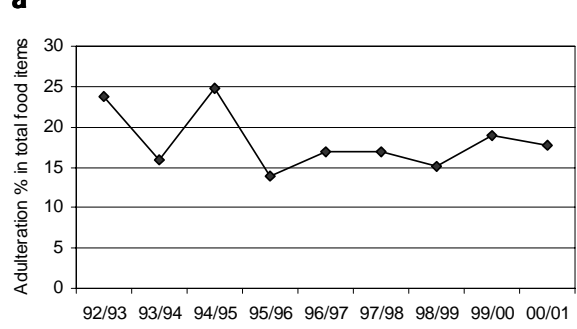

b

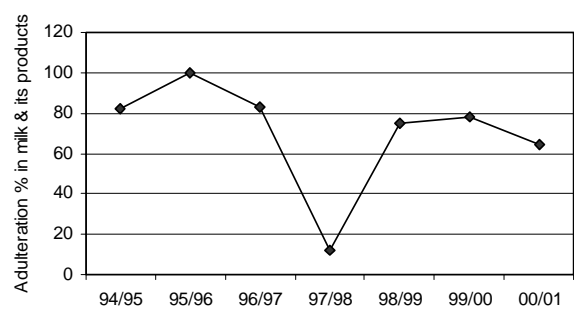

C

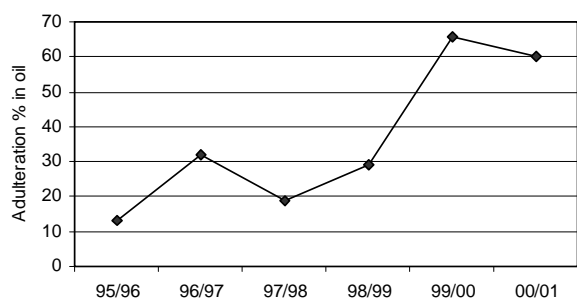

d

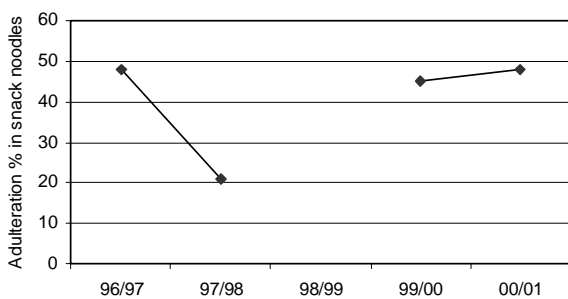

FIGURE 1. Food adulteration in different food products - total food items (a), milk and mild products (b), oil (c), and snack noodles (d). Values in parentheses are the number of samples studied. (CFRL 1998/1999, DFTQC 2000/2001) 
TABLE 1. Conflicting values for pasteurized milk and milk products published in two DFTQC bulletins

\begin{tabular}{|c|c|c|}
\hline \multirow[t]{2}{*}{ Year } & \multicolumn{2}{|c|}{ Marketed itemsin milkand milkproductswith adulteration (\%) } \\
\hline & 1998/99bulletin & 2000/01bulletin \\
\hline $1995 / 96$ & 106 (one hundred and six) & 100 (one hundred) \\
\hline 1996/97 & 62.5 (sixty-two point five) & 83.3(eighty-three point three) \\
\hline $1997 / 98$ & 6.3(sixpoint three) & 12.3 (twelve point three) \\
\hline 1998/99 & 75 (seventy-five) & 7.5 (seven point five) \\
\hline
\end{tabular}

instantnoodles consumed during 1999-2000 were found to be substandard due to the adulteration with inediblecoloursand other contaminants. The DFTQC bulletin states that noodles have been found substandard sinceregular monitoringbegan in 1996 (see Figure 1d). Similarly, nearlyone third of the brands of mineral water consumed in the past four years were substandard due to mesophilic contaminants.

The expanding practice of food adulteration is directly attributable to the negligence of the concerned agencies, officials, and experts. Regular inspection isindispensable. But research is not enough. DFTQC can and should control the appalling situation by promptly releasing evidenceof adulteration to the general public via the mass media. In so doing, DFTQC must takesteps to present its data and analyses more logically and consistently. For instance, thedata on pasteurized milk and milk products of 1998/ 99 appears differently in the bulletins of 1998/99and 2000/2001 (seeTable1). The table clarifies the credibility of the reports of responsible organizations. Three different figures are given for the incidence of adulteration of pasteurized milkin 1998/99: 75 (seventy-five) percent in the main table and 90 (ninety) percent in text of the 1998/
99 bulletin, 7.5 (seven point five) percent in 2000/01 bulletin.

Food adulteration reports from throughout the country show that the situation is critical. It is up to consumers to insist that something bedone, and quickly.

Rajendra Uprety is a member of ExecutiveCouncil, Nepal Chemical Society E-mail: upretyrajendra@yahoo.com

\section{References}

1) CFRL. 1996/ 1997. Annual bulletin 1996/ 1997. Kathmandu: Central Food Research Laboratory, Ministry of Agriculture and Co-operative, HMGN. 160p

2) CFRL. 1997/ 1998. Annual bulletin 1997/ 1998. Kathmandu: Central Food Research Laboratory, Ministry of Agriculture and Co-operative, HMGN.124p

3) CFRL. 1998/ 1999. Annual bulletin 1998/ 1999. Kathmandu: Central Food Research Laboratory, Ministry of Agriculture and Co-operative, HMGN.50p

4) DFTQC. 2000/2001. Annual bulletin 2000/ 2001. Kathmandu: Department of Food Technology and Quality Control, Ministry of Agricultureand Co-operative, HMGN. 160 p

\section{www.himjsci.com}

Now, www.himjsci.com contains not only the materials published in print edition of Himalayan J ournal of Sciences. It has a good resource for a scientist to write a reserach paper and much more.

\section{Available items and sections:}

- Stories published in print editions

- 'Guide to Authors' for submitting a paper to HJS

- 'How to Write a Scientific Paper': A complete guide for reserch paper writing

- How to write a review paper, book review etc.

- Using good English, avoiding errors and jargons

- Selected journal title word abbreviations approved by HJS

- Abbreviation symbols accepted by HJS

Websitewith all thesecontents will bereadyat theend of Sept 2003 